\title{
Antimicrobial Activity of Various Plant Extracts on Pseudomonas Species Associated with Spoilage of Chilled Fish
}

\author{
Osan Maroof Bahurmiz ${ }^{1 *}$, Rosma Ahmad ${ }^{2}$, Noryati Ismail ${ }^{3}$, Frederick Adzitey ${ }^{4}$, \\ Shaida-Fariza Sulaiman ${ }^{5}$
}

\author{
${ }^{I}$ Department of Food and Fish Technology, Faculty of Environmental Sciences and Marine Biology, Hadhramout University, Mukalla, \\ Hadhramout, Yemen. \\ ${ }^{2}$ Bioprocess Technology Division, School of Industrial Technology, Universiti Sains Malaysia, 11800 Penang, Malaysia. \\ ${ }^{3}$ Food Technology Division, School of Industrial Technology, Universiti Sains Malaysia, 11800 Penang, Malaysia. \\ ${ }^{4}$ Department of Animal Science, Faculty of Agriculture, University for Development Studies, Tamale, Ghana. \\ ${ }^{5}$ School of Biological Sciences, Universiti Sains Malaysia, 11800 Penang, Malaysia.
}

\section{A R T I C LE IN F O}

Article history:

Received 28 January 2016

Accepted 29 August 2016

Available online, ISSN: 2148-127X

Keywords:

Fish spoilage

Pseudomonas

Plant extracts

Antimicrobial activity

${ }^{*}$ Corresponding Author:

E-mail: : osan79@hotmail.com

\begin{abstract}
A B S T R A C T
The antimicrobial activity of various plant extracts on Pseudomonas bacteria isolated from spoiled chilled tilapia (Oreochromis sp.) was evaluated in this study. In the first stage of this study, red tilapia was subjected to chilled storage $\left(4^{\circ} \mathrm{C}\right)$ for 3 weeks, and spoilage bacteria were isolated and identified from the spoiled fish. Pseudomonas was the dominant bacteria isolated from the spoiled fish and further identification revealed that $P$. putida, P. fluorescens and Pseudomonas spp. were the main species of this group. In the second stage, methanolic extracts of 15 selected plant species were screened for their antimicrobial activity, by agar disc diffusion method, against the Pseudomonas isolates. Results indicated that most of the extracts had different degrees of activity against the bacterial isolates. The strongest activity was exhibited by bottlebrush flower (Callistemon viminalis) extract. This was followed by extracts from guava bark (Psidium guajava) and henna leaf (Lawsonia inermis). Moderate antimicrobial activities were observed in extracts of clove (Syzygium aromaticum), leaf and peel of tamarind (Tamarindus indica), cinnamon bark (Cinnamomum zeylanicum), wild betel leaf (Piper sarmentosum) and fresh thyme (Thymus spp.). Weak or no antimicrobial activity was observed from the remaining extracts. The potential antimicrobial activity shown by some plant extracts in this study could significantly contribute to the fish preservation.
\end{abstract}

\section{Introduction}

The quality deterioration of fresh fish starts by various autolytic (enzymatic) reactions and then subsequent spoilage is principally caused by bacterial growth and its relative reactions (Gram and Huss, 1996). At low storage temperatures, Gram-negative psychrotrophic organisms such as Pseudomonas, Alteromonas and Shewanella are the predominant organisms found on aerobically stored fish (Hobbs, 1991). Among these, Pseudomonas spp. have been reported as the typical specific spoilage organism (SSO) for freshwater fish and fish from warm waters (Gram and Huss, 1996; Gram and Dalgaard, 2002).

Food antimicrobials, including food preservatives have been widely used to inhibit growth of spoilage and food-borne bacteria. However, in the recent years, the synthetic nature of many antimicrobial agents is of much consideration to customer's health. Besides, the strong awareness for more nutritious, healthy and safe foods had steadily increased the demand for natural food additives (Burt, 2004; Tajkarimi et al., 2010). Plants, herbs and spices and their extracts have been used for centuries as traditional medicines, food flavours and preservatives, or even cosmetic materials (Tajkarimi et al., 2010; Gyawali and Sallam, 2014). Scientific reports have also shown potential antimicrobial activity of extracts from various herbs and spices on a wide variety of microorganisms, including food-borne pathogens and spoilage bacteria (Ceylan and Fung, 2004; Oonmetta-aree et al., 2006; Yano et al., 2006; Tajkarimi et al., 2010; Weerakkody et al., 2010; Abd Aziz et al., 2011; Devatkal et al., 2013; Velu et al., 2014; Baljeet et al., 2015). However, less attention has been paid in evaluating their activity against spoilage bacteria of fish, especially Pseudomonas species. Studies of Corbo et al. $(2008,2009)$ could be so far the most relevant documents on this subject. The authors screened the antimicrobial activity of commercial extracts of green tea, rosemary, grapefruit seed and lemon, along with the active compounds of some essential oils, against the main spoilage bacteria of marine fish, Shewanella putrefaciens and Photobacterium phosphoreum. The most 
potent activity of this study has been shown for thymol and lemon extract, even at their low concentrations (Corbo et al., 2009). Apart from the above mentioned reports, other studies conducted in this field have used commercial plant essential oils (Mejlholm and Dalgaard, 2002; Mahmoud et al., 2004; Gómez-Estaca et al., 2010).

Crude extracts of various plant species from nine families: Alliaceae, Anacardiaceae, Fabaceae/Leguminosae, Lamiaceae, Lauraceae, Lythraceae, Myrtaceae, Piperaceae and Zingiberaceae (Table 1) were selected to be evaluated in the current study. Most of these plants such as cinnamon, clove, galangal, garlic, ginger, guava, henna, mint, oregano, tamarind and thyme have commonly been used as spices and herbs, food ingredients, and/or traditional medical purposes (Peter, 2001; Oonmetta-aree et al., 2006; Yano et al., 2006; Abukakar et al., 2008). Some species such as henna ( $L$. inermis), wild betel leaf (P. sarmentosum) and Java/wax apple (S. samarangense) are locally known as medicinal plants in Malaysia (Rahman et al., 1999; Abd Aziz et al., 2011). The antimicrobial activity of various fractions obtained from many of these plants has been scientifically proofed (Rahman et al., 1999; Ceylan and Fung, 2004; Yano et al., 2006; Abukakar et al., 2008; Ernawita, 2008; Tajkarimi et al., 2010; Abd Aziz et al., 2011).

However, to the best of our knowledge, none of extracted materials from these plants have yet been tested for their antimicrobial activity against the specific spoilage bacteria of fish and fishery products. Thus, the objective of the present study was to evaluate the antimicrobial potential of selected plant extracts on Pseudomonas species associated with spoilage of chilled fish. The study also investigated the dominant microbial species responsible for spoilage of chilled tilapia.

\section{Materials and Methods}

\section{Fish and Storage Conditions}

Red tilapia, Oreochromis sp., was freshly harvested from the aquaculture facilities of Universiti Sains Malaysia, Penang, Malaysia. The fishes were wrapped individually in oxygen-permeable polyethylene bags and stored aerobically at $4^{\circ} \mathrm{C}$. Microbiological and sensorial analyses were performed on day $0,7,14$ and 21 of storage.

\section{Enumeration and Isolation of Bacteria}

For bacterial enumeration, $0.1 \mathrm{ml}$ decimal dilution series of the fish homogenate was prepared in $0.1 \%(\mathrm{w} / \mathrm{v})$ peptone water (Merck, Darmstadt, Germany). It was then spread plated on plate count agar (PCA) (Merck, Darmstadt, Germany) and cetrimide fucidin cephaloridine agar (CFC) (Oxoid, Basingstoke, United Kingdom) for enumeration of total viable count (TVC) and pseudomonads count, respectively. In both cases, plates were incubated at $25^{\circ} \mathrm{C}$ for a minimum of 2 days. Two replicates of at least three appropriate dilutions were enumerated. Plates containing 30-300 colonies were counted, and values of colony forming units, CFU/g of fish tissue were calculated.
Isolation of spoilage bacteria was performed from PCA and CFC plates of spoiled fish. Spoilage stage was defined when pseudomonads count reached $10^{8}-10^{9}$ $\mathrm{CFU} / \mathrm{g}$. This level has been recommended for the microbial rejection of fresh fish stored aerobically at chilled temperatures (Gram and Huss, 1996). The spoilage of fish was also confirmed by the sensory evaluation. Respective plates of both media that had 3050 colonies were kept $\left(4^{\circ} \mathrm{C}\right)$ for subsequent bacterial isolation and further identification of spoilage microorganisms. A total of 90 well isolated colonies, comprising 60 and 30 isolates from PCA and CFC plates, respectively, were picked randomly. Isolates were further purified by streaking twice in nutrient agar, NA (Merck, Darmstadt, Germany)at $25^{\circ} \mathrm{C} / 2$ days.

\section{Identification of Isolates}

Each of the 90 isolates was examined at $25^{\circ} \mathrm{C}$ using the following tests: Gram reaction (Gregersen, 1978), motility and cell shape (phase-contrast microscopy after growth in nutrient broth for 16-24 h), catalase (3\% hydrogen peroxide); production of oxidase using oxidase test strips, fermentation/oxidation test for glucose metabolism in O-F medium of Hugh and Leifson (Hugh and Leifson, 1953) and production of $\mathrm{H}_{2} \mathrm{~S}$ in triple sugar iron agar. The isolated strains were then grouped to the genus level using the schemes proposed by Shewan et al. (1960), Dainty et al. (1979), Bagge-Ravn et al. (2003) and Lalitha and Surendran (2006) for the identification of bacteria isolated from meat and aquatic products. The information of Tryfinopoulou et al. (2001) was also referred to differentiate between the CFC isolates.

Gram-negative, motile rods, oxidase and catalase positive and non-fermentation of glucose, with no production of $\mathrm{H}_{2} \mathrm{~S}$ were used as prospective identifications for Pseudomonas spp. These prospective isolates were also checked for their ability to grow at various temperatures $\left(4,37\right.$, and $\left.42^{\circ} \mathrm{C}\right)$. The identity of pseudomonads was further confirmed by the API 20NE System (BioMérieux, France). Reference strain LMBF481 (Pseudomonas fluorescens) isolated from spoiled chilled gilt-head sea bream (Sparus aurata) was used in this assay (Tryfinopoulou et al., 2002).

\section{Sensory Evaluation}

The sensory test was designed to evaluate the overall acceptability of chilled tilapia based on a modified scheme from Liu et al. (2010) using the following classifications: fresh, acceptable, neutral, spoiled and rotten.

\section{Plant Samples}

Fifteen (15) different plant species made up of spices, herb and other natural plants were used to prepare 19 extracts (Table 1). These plants were collected from the Botanical Garden at School of Biological Sciences, Universiti Sains Malaysia or purchased from Penang's local market in terms of fresh or dry matter. Their identities were checked by morphological examination and were compared with the herbarium specimens. 
Table 1 List of plant extracts used in this study

\begin{tabular}{l|lll}
\hline \multicolumn{1}{c}{ Common name } & \multicolumn{1}{c}{ Botanical name } & \multicolumn{1}{c}{ Family } & Extracted part \\
\hline Bottlebrush & Callistemon viminalis & Myrtaceae & Flower \\
Bottlebrush & Callistemon viminalis & Myrtaceae & Leaf \\
Cinnamon & Cinnamomum zeylanicum & Lauraceae & Bark \\
Clove & Syzygium aromaticum & Myrtaceae & Bud \\
Galanga & Alpinia galanga & Zingiberaceae & Rhizome \\
Garlic & Allium sativum & Alliaceae & Bulb \\
Ginger & Zingiber officinale & Zingiberaceae & Rhizome \\
Guava & Psidium guajava & Myrtaceae & Bark \\
Java/wax apple & Syzygium samarangense & Myrtaceae & Leaf \\
Henna & Lawsonia inermis & Lythraceae & Leaf \\
Mango & Mangifera indica & Anacardiaceae & Bark \\
Mint & Mentha arvensis & Lamiaceae & Aerial part \\
Oregano & Oreganum spp. & Lamiaceae & Aerial part (fresh) \\
Oregano & Oreganum spp. & Lamiaceae & Aerial part (dry) \\
Tamarind & Tamarindus indica & Fabaceae/Leguminosae & Leaf \\
Tamarind & Tamarindus indica & Fabaceae/Leguminosae & Peel \\
Thyme & Thymus spp. & Lamiaceae & Aerial part (fresh) \\
Thyme & Thymus spp. & Lamiaceae & Aerial part (dry) \\
Wild betel leaf & Piper sarmentosum & Piperaceae & Leaf \\
\hline
\end{tabular}

\section{Preparation of Plant Extracts}

The part of each plant sample used was cleaned, washed with running tap water, crushed, sliced and/or ground into an appropriate size. Each sample was completely soaked in $80 \%$ methanol (Analytical grade; Fisher Scientific, U.K.) and heated on a boiling bath (Protech BB-6TS, Malaysia) for $1 \mathrm{~h}$, then covered with aluminium foil and left at room temperature for $24 \mathrm{~h}$. The extracts were filtered using Whatman filter paper No 1 and the filtrates were first evaporated at $50-60^{\circ} \mathrm{C}$ (Eyela $\mathrm{N}-100$, Japan) then dried in a tray dryer at $50^{\circ} \mathrm{C}$ (Protech FDA-720, Malaysia). A portion of each dried crude extract was dissolved in $25 \%$ dimethyl sulfoxide (DMSO) (Merck, Darmstadt, Germany) by sonication (JAC-2010 (P), Kodo, South Korea) and vortex continuously to a final concentration of $100 \mathrm{mg} / \mathrm{ml}(10 \%, w / v)$, and then sterilized by filtration using $0.20 \mu \mathrm{m}$ Millipore syringe filters (Sartorius, Germany). A combination $(1: 1 \mathrm{v} / \mathrm{v})$ of the most two potential extracts was also prepared.

\section{Preparation of Pseudomonas Inoculum}

Cultures from each of the three Pseudomonas species isolated from spoiled tilapia were used in this assay. For each species, a loopful from a $25^{\circ} \mathrm{C} / 48 \mathrm{~h}$ nutrient agar plate was inoculated into $10 \mathrm{ml}$ of nutrient broth and incubated at $25^{\circ} \mathrm{C}$ and $100 \mathrm{rpm}$ for $16-18 \mathrm{~h}$ to achieve cultures at exponential phase containing $10^{7}-10^{8} \mathrm{CFU} / \mathrm{ml}$. Each of the bacterial species was then diluted with sterile saline, $0.9 \% \mathrm{NaCl}$ w/v solution ( $\mathrm{R} \& \mathrm{M}$ Chemicals, UK) to achieve working cultures of approximately $10^{7} \mathrm{CFU} / \mathrm{ml}$. Working cultures of each individual isolate was used for the screening assay of each plant material. Besides, a cocktail of the three Pseudomonas cultures, which was similarly prepared by mixing equal amounts of their respective individual cultures, was further used for screening the most potential extracts and their respective combination.

\section{Antimicrobial Activity of Extracts by Agar Disc Diffusion Method}

Tests for individual and combined plant extracts, of equal concentrations of $100 \mathrm{mg} / \mathrm{ml}$, were conducted by standard disk diffusion agar method (Clinical and Laboratory Standards Institute (CLSI), 2009), after minor modifications. A suspension $\left(10^{7} \mathrm{CFU} / \mathrm{ml}\right)$ of each microorganism or their cocktail mixture was spread plated on the entire surface of Müeller-Hinton agar (Oxoid, Basingstoke, United Kingdom) plates. Then, a $20 \mu \mathrm{l}$ of each diluted extract was added on its respective sterile 6 $\mathrm{mm}$ discs (Oxoid, Basingstoke, United Kingdom). Sterile $25 \%$ DMSO was used as a negative control. The plates were allowed to stand for about $30-60 \mathrm{~min}$ at room temperature, before being incubated at $25^{\circ} \mathrm{C}$. After $48 \mathrm{~h}$ of incubation, each plate was examined for the presence of the zone of inhibition, measured to the nearest whole millimetre, including the diameter of the disc.

Besides, the two most effective extracts (bottlebrush flower and guava tree bark) were selected to evaluate the potential of any synergetic effect that might occurred when combined. This antimicrobial assay was conducted for each of these extracts as well as their respective combinations against the cocktail culture of the three Pseudomonas species, following the same procedure used for the individual extracts.

Triplicate samples of each antimicrobial agent were employed in this test, and results were calculated as mean $\pm \mathrm{SD}$.

\section{Statistical Analysis}

Results of bacterial count were converted into logarithms of the number of colony forming units per $\mathrm{g}$ of fish tissue $(\log \mathrm{CFU} / \mathrm{g})$. One-way analysis of variance (ANOVA) using the SPSS program, 17.0 for Windows (SPSS lnc., Chicago, IL, USA) was performed to test the antimicrobial activity (inhibition zone) of different plant 
extracts against Pseudomonas isolates. Differences between means were determined by Duncan's Multiple Range test (Duncan, 1955) and were considered to be significant when $P$-values were $<0.05$.

\section{Results}

\section{Microbiological and Sensorial Changes of Chilled Tilapia}

Changes in microbiological and sensorial values of tilapia during chilled storage are shown in Table 2. Initially, day 0 , the fish was very fresh, with bacterial count of $4.13 \mathrm{Log}$ CFU/g and 3.11 Log CFU/g for TVC and Pseudomonas, respectively. Over the first week of storage, a sharp increase in bacterial counts was observed, but the overall quality of fish was still acceptable. Then by day-14, the bacterial count of fish had increased above Log $8 \mathrm{CFU} / \mathrm{g}$ for both bacterial types. Sensory spoilage was also visible at this stage. Accordingly, isolation of bacterial species was performed in day 14. Further storage to day 21 had no significant change on the bacterial count, but the spoilage rate was further increased and caused the fish to become rotten.

\section{Bacterial Identification}

The identification of the 60 isolates from the PCA plates of spoiled tilapia is shown in Table 3 . The majority of these isolates (86.7\%) were identified as Gramnegative rods. About half of them (equivalent to $43.3 \%$ of total isolates) were motile, oxidase and catalase positive, non-fermentative of glucose and did not produce $\mathrm{H}_{2} \mathrm{~S}$ in TSI tubes. Accordingly, they were identified as pseudomonads. The second group of isolates (18.3\%) showed similar characteristics with pseudomonads, except for their capability to produce $\mathrm{H}_{2} \mathrm{~S}$; consequently they were identified as Shewanella putrefaciens. Moraxella was also found as the third largest group of the microflora (15.0\%). The remaining Gram-negative rods (6 isolates) consisted of Acinetobacter ( 3 isolates) and Aeromonas ( 3 isolates). On the other hand, the Gram-positives (13.3\%) consisted of Staphylococcus, Micrococcus and two unidentified isolates.

For the 30 isolates of the CFC plates, almost all of them (29 isolates) were Gram-negative, motile rods, oxidase and catalase positive, non-glucose fermenter and could grow at 4 and $37^{\circ} \mathrm{C}$. None of them produced $\mathrm{H}_{2} \mathrm{~S}$, or grew at $42^{\circ} \mathrm{C}$. Likewise, the reference strain (LMBF481) exhibited the same characteristics. Thus these isolates were identified as pseudomonads. Among these Pseudomonas isolates, the API 20NE system was able to identify species of $P$. fluorescens $(25 \%)$ and $P$. putida (41.7\%), whereas the remaining isolates of this genus were clustered as Pseudomonas spp. (33.3\%).

Besides, the one non-Pseudomonas isolate was differed on its capability to ferment glucose in the $\mathrm{O} / \mathrm{F}$ medium as well as acid and gas formation in TSI agar. This strain was identified as Aeromonas spp.

\section{Antimicrobial Activity of Extracts}

The individual extracts showed various degrees of antimicrobial activity against the three Pseudomonas species (Table 4). In general, P. fluorescens was least sensitive to all extracts. Almost the same trend of sensitivity was exhibited by $P$. putida and Pseudomonas spp.

Table 2 Changes in bacterial count (Log CFU/g) and acceptability of red tilapia during chilled storage

\begin{tabular}{l|ccc}
\hline \multirow{2}{*}{ Storage days } & \multicolumn{2}{c}{ Bacterial count } & Acceptability \\
\cline { 2 - 4 } Day-0 & TVC & Pseudomonas & Fresh \\
Day-7 & $4.13 \pm 0.03^{\mathrm{c}}$ & $3.11 \pm 0.05^{\mathrm{c}}$ & Acceptable \\
Day-14 & $7.13 \pm 0.06^{\mathrm{b}}$ & $6.79 \pm 0.08^{\mathrm{b}}$ & Spoiled \\
Day-21 & $8.88 \pm 0.11^{\mathrm{a}}$ & $8.41 \pm 0.11^{\mathrm{a}}$ & Rotten \\
\hline
\end{tabular}

Mean values in the same column with different superscripts were significantly different $(\mathrm{P}<0.05)$.

Table 3 Characterization of bacterial isolates from the PCA plates of spoiled chilled tilapia

\begin{tabular}{c|cccccccc}
\hline $\begin{array}{c}\text { No. of } \\
\text { isolates }\end{array}$ & $\begin{array}{c}\text { Gram } \\
\text { Reaction }\end{array}$ & Shape & Motility & Oxidase & Catalase & $\begin{array}{c}\text { Glucose } \\
\text { metabolism }\end{array}$ & $\mathrm{H}_{2} \mathrm{~S}$ & Identification \\
\hline 26 & - & Rod & + & + & + & $\mathrm{O}$ & - & Pseudomonas \\
11 & - & Rod & + & + & + & $\mathrm{K}$ & + & Shewanella \\
9 & - & Rod & - & + & + & $\mathrm{K}$ & - & Moraxella \\
3 & - & Rod & - & + & + & $\mathrm{NC}$ & - & Acinetobacter \\
3 & - & Rod & + & + & + & $\mathrm{F}$ & - & Aeromonas \\
5 & + & Cocci & - & - & + & $\mathrm{F}$ & $\mathrm{NR}$ & Staphylococcus \\
1 & + & Cocci & - & - & + & $\mathrm{NC}$ & $\mathrm{NR}$ & Micrococcus \\
1 & + & Rod & - & - & - & $\mathrm{F}$ & $\mathrm{NR}$ & Unknown \\
1 & + & Rod & - & - & + & $\mathrm{F}$ & $\mathrm{NR}$ & Unknown \\
\hline
\end{tabular}

+/-; Positive/negative reaction, F; fermentation, K; alkaline, NC; no change, O; oxidation, NR: not run 
Table 4 Antimicrobial activity (inhibition zone, $\mathrm{mm}$ ) of selected plant extracts against Pseudomonas isolates

\begin{tabular}{l|cccc}
\hline \multicolumn{1}{c|}{ Plant extract } & P. fluorescens & P. putida & Pseudomonas spp. & Average \\
\hline Bottlebrush (flower) & $13.83 \pm 1.0^{\mathrm{a}}$ & $22.50 \pm 0.5^{\mathrm{a}}$ & $21.33 \pm 2.0^{\mathrm{a}}$ & $19.22 \pm 4.7^{\mathrm{a}}$ \\
Bottlebrush (leaf) & $9.75 \pm 0.5^{\mathrm{f}}$ & $13.75 \pm 0.7^{\mathrm{d}}$ & $14.33 \pm 0.1^{\mathrm{d}}$ & $12.61 \pm 2.5^{\mathrm{e}}$ \\
Cinnamon & $7.67 \pm 0.6^{\mathrm{gh}}$ & $12.00 \pm 0.0^{\mathrm{e}}$ & $12.83 \pm 0.3^{\mathrm{ef}}$ & $10.83 \pm 2.8^{\mathrm{fgh}}$ \\
Clove & $11.58 \pm 0.5^{\mathrm{bcd}}$ & $14.08 \pm 0.6^{\mathrm{d}}$ & $14.08 \pm 0.1^{\mathrm{d}}$ & $13.25 \pm 1.4^{\mathrm{d}}$ \\
Galanga & $\mathrm{ND}$ & $8.00 \pm 0.0^{\mathrm{i}}$ & $9.00 \pm 0.3^{\mathrm{i}}$ & $7.67 \pm 1.5^{\mathrm{l}}$ \\
Garlic & $\mathrm{ND}$ & $\mathrm{ND}$ & $\mathrm{ND}$ & $\mathrm{ND}$ \\
Ginger & $\mathrm{ND}$ & $\mathrm{ND}$ & $\mathrm{ND}$ & $\mathrm{ND}$ \\
Guava & $12.00 \pm 0.0^{\mathrm{b}}$ & $19.25 \pm 0.9^{\mathrm{b}}$ & $19.17 \pm 0.8^{\mathrm{b}}$ & $16.81 \pm 4.1^{\mathrm{b}}$ \\
Henna & $11.83 \pm .04^{\mathrm{bc}}$ & $15.67 \pm 0.6^{\mathrm{c}}$ & $15.67 \pm 0.3^{\mathrm{c}}$ & $14.39 \pm 2.2^{\mathrm{c}}$ \\
Java/wax apple & $10.92 \pm 1.0^{\mathrm{cde}}$ & $13.42 \pm 0.4^{\mathrm{d}}$ & $13.67 \pm 0.8^{\mathrm{de}}$ & $12.67 \pm 1.5^{\mathrm{e}}$ \\
Mango & $9.50 \pm 0.5^{\mathrm{f}}$ & $10.83 \pm 0.1^{\mathrm{f}}$ & $10.42 \pm 0.1^{\mathrm{h}}$ & $10.25 \pm 0.7^{\mathrm{h}}$ \\
Mint & $7.00 \pm 0.0^{\mathrm{h}}$ & $7.00 \pm 0.0^{\mathrm{j}}$ & $9.00 \pm 0.0^{\mathrm{i}}$ & $7.67 \pm 1.2^{\mathrm{l}}$ \\
Oregano (fresh) & $8.17 \pm 0.3^{\mathrm{g}}$ & $8.42 \pm 0.7^{\mathrm{hi}}$ & $8.33 \pm 0.6^{\mathrm{i}}$ & $8.31 \pm 0.1^{\mathrm{k}}$ \\
Oregano (dry) & $8.00 \pm 0.3^{\mathrm{g}}$ & $8.92 \pm 0.1^{\mathrm{gh}}$ & $12.00 \pm 0.9^{\mathrm{fg}}$ & $9.64 \pm 2.1^{\mathrm{i}}$ \\
Tamarind (leaf) & $10.83 \pm 0.3^{\text {de }}$ & $11.17 \pm 0.3^{\mathrm{ef}}$ & $11.00 \pm 0.0^{\mathrm{gh}}$ & $11.00 \pm 0.2^{\text {fg }}$ \\
Tamarind (peel) & $10.25 \pm 0.5^{\mathrm{ef}}$ & $11.75 \pm 0.0^{\mathrm{e}}$ & $11.17 \pm 0.8^{\mathrm{gh}}$ & $11.06 \pm 20.8^{\mathrm{f}}$ \\
Thyme (fresh) & $8.17 \pm 0.3^{\mathrm{g}}$ & $12.00 \pm 1.4^{\mathrm{e}}$ & $11.63 \pm 0.5^{\mathrm{gh}}$ & $10.60 \pm 2.1^{\text {fgh }}$ \\
Thyme (dry) & $8.08 \pm 0.1^{\mathrm{g}}$ & $8.42 \pm 0.7^{\mathrm{hi}}$ & $10.50 \pm 0.0^{\mathrm{h}}$ & $9.00 \pm 1.3^{\mathrm{j}}$ \\
Wild betel leaf & $10.00 \pm 1.3^{\mathrm{ef}}$ & $9.67 \pm 0.6^{\mathrm{g}}$ & $11.50 \pm 1.3^{\mathrm{gh}}$ & $10.39 \pm 1.0^{\mathrm{gh}}$ \\
\hline
\end{tabular}

Values were reported as means \pm S.D. of triplicate groups. Mean values in the same column with different superscripts were significantly different $(\mathrm{P}<0.05) . \mathrm{ND}=$ non-detectable.

Among the 19 extracts tested, bottlebrush flower had the strongest antimicrobial activity against all of the three Pseudomonas species. This was followed by guava tree bark extract and henna leaf extract. Moderate antimicrobial activities were observed by seven extracts in the following descending order: clove, Java apple, bottlebrush leaf, tamarind peel and leaf, cinnamon and fresh thyme. Weak activity $(\leq 10 \mathrm{~mm})$ was given by mango tree bark, wild betel leaf, dry oregano and dry thyme, fresh oregano, mint and galangal extracts. No antimicrobial activity was observed for garlic and ginger extracts against Pseudomonas species.

No synergistic effect on the antimicrobial activity was achieved by the combination of the two most effective plant extracts; bottlebrush flower and guava tree bark against the cocktail culture of the three Pseudomonas species. The inhibitory value obtained by the combination of these two extracts $(16.83 \mathrm{~mm})$ was even lower $(\mathrm{P}<0.05)$ than that of bottlebrush flower extract $(17.67$ $\mathrm{mm})$.

\section{Discussion}

At the point of sensory spoilage, the pseudomonads count of stored tilapia was within the range of $10^{8}-10^{9}$ $\mathrm{CFU} / \mathrm{g}$, which has been recommended as the level of microbial rejection of chilled fish (Gram and Huss, 1996). Similar Pseudomonas counts have been found in air packaged tilapia fillet at the end of shelf-life storage at $1^{\circ} \mathrm{C}$ (Odoli, 2009). The domination of Pseudomonas species observed in the current work is identical to spoilage bacterial of aerobically-stored chilled tilapia (Surendran et al., 1989; Odoli, 2009) and freshwater fish (Surendran et al., 1989; Gram et al., 1990). Species of $P$. putida and $P$. fluorescens identified in this study are commonly isolated from fish stored at chilled temperatures (Stenström and Molin, 1990; Tryfinopoulou et al., 2002). The domination of these bacteria over other fish microflora at such storage conditions could be attributed to their ability to utilise a variety of compounds, like the non-protein nitrogen (NPN) fraction in the fish muscle quickly and efficiently (Liston, 1980; Gram, 1993).

Among all the 19 plant extracts screened, the extract of bottlebrush flower, $C$. viminalis, showed the highest antimicrobial activity against Pseudomonas species. In comparison to the results of this study, methanolic extracts of leaf and flower from two other species of Callistemon ( $C$. citrinus and $C$. salignus) displayed potential antibacterial activities against some Grampositive and Gram-negative bacteria including $P$. fluorescens (Cock, 2008); where the antimicrobial activity was higher in the flower fraction than the leaf fraction. The antimicrobial activity of various fractions of the leaf part of $C$. viminalis harvested from the same source as this study has been reported by Ernawita (2008). Results showed moderate inhibitory activity of the methanolic extract, particularly towards Gram-positive bacteria. This activity was beyond that of the essential oil fraction, but less than those for non-polar extracts. Analysis conducted by the latter study for three different fractions indicated eucalyptol as the major component, in additional to another three components ( $\alpha$-pinene, $\alpha$-phellandrene and limonene) that were common in all fractions tested. Moreover, other data on the essential oil fraction of $C$. viminalis has generally reported 1,8-cineole, $\alpha$-pinene and $\alpha$-terpineol as the major components, while minor constituents were $\alpha$-thujene, $\beta$-pinene, myrcene, $p$ cymene, $\gamma$-terpinene, terpinolene, linalool, transpinocarveol, borneol, $\alpha$-humulene, allo-aromadendrene, 
spathulenol and globulol (Brophy et al., 1997; Srivastava et al., 2003). The antimicrobial role of cineole or cineolerich essential oils has been reported towards a wide range of bacteria (Pattanik et al., 1997; Sato et al., 2007).

The second potent extract reported in the current study was derived from the bark of guava tree, $P$. guajava. Some studies have also demonstrated the antimicrobial activity of the guava bark extract against Pseudomonas strains. Abdelrahim et al. (2002) observed good antibacterial activities of its methanolic bark extracts towards $P$. aeruginosa as well as other Gram-positive and Gram-negative microorganisms. Ethanolic extracts of guava leaf showed antimicrobial activities against a wide spectrum of food-borne pathogenic and spoilage bacteria including $P$. putida and $P$. aeruginosa (Hoque et al., 2007). The major components of the guava tree bark are tannin (12-30\%), resin and crystals of calcium oxalate (Khan and Ahmad, 1985, Burkill and Dalziel, 1997). Thus, the antimicrobial activity of this extract could be attributed to these components, particularly tannins (Ali and Shamsuzzaman, 1996).

Potential antimicrobial activity was also showed by henna (L. inermis) leaf extract. In agreement with our study, the methanolic extract of the leaf part of this plant was found to be very active against $P$. fluorescens (Bonjar, 2004). Alike, ethanolic extracts of L. inermis exhibited potential antibacterial activity against $V$. cholerae, V. parahaemolyticus and 12 multidrug resistant isolates of $V$ cholerae (Sharma et al., 2009). The authors reported that the presence of tannin in these extracts could be responsible for the vibriocidal activity.

Some studies have reported greater inhibitory effects on various bacterial species using extracts of plant-origin applied in combination than if they were used separately (Burt, 2004; Lee and Stein, 2011). This effect has been suggested to be as a result of synergistic actions of specific compounds with different biochemical properties present in the mixture (Burt, 2004; Gyawali and Sallam, 2014). However, in the present study, the combination of $C$. viminalis and $P$. guajava extracts had no synergistic action against Pseudomonas. This observation was similarly reported by Gutierrez et al. (2008) where several combinations of various plant essential oils failed to achieve synergistic inhibitory effect against four pathogenic bacteria. In fact, mechanisms involved in creating synergistic actions in such combinations are likely to be very complicated and still unclear (Singh et al., 2007).

In conclusion, the potential inhibitory activity of crude extracts of bottlebrush flower, guava tree bark and henna leaf on Pseudomonas isolates associated with microbial spoilage of chilled fish could significantly contribute as natural antimicrobial alternatives for fish preservation.

\section{References}

Abd Aziz SM, Low CN, Chai LC, Abd Razak SSN, Selamat J, Son R, Sarker MZI, Khatib A. 2011. Screening of selected Malaysian plants against several food borne pathogen bacteria. Int. Food Res. J. 18(3): 1195-1201.
Abdelrahim SI, Almagboul AZ, Omer MEA, Elegami A. 2002. Antimicrobial activity of Psidium guajava L. Fitoterapia 73(78): 713-715.

Abukakar MG, Ukwuani AN, Shehu RA. 2008. Phytochemical screening and antibacterial activity of Tamarindus indica pulp extract. Asian J. Biochem. 3(2): 134-138.

Ali AM, Shamsuzzaman M. 1996. Isolation and characterization of antibacterial constituents from the bark of Psidium guajava. Bangladesh J. Sci. Ind. Res. 31: 133-139.

Bagge-Ravn D, Ng Y, Hjelm M, Christiansen JN, Johansen C, Gram L. 2003. The microbial ecology of processing equipment in different fish industries - analysis of the microflora during processing and following cleaning and disinfection. Int. J. Food Microbiol. 87(3): 239-250.

Baljeet S, Simmy G, Ritika Y, Roshanlal Y. 2015. Antimicrobial activity of individual and combined extracts of selected spices against some pathogenic and food spoilage microorganisms. Int. Food Res. J. 22(6): 2594-2600.

Bonjar S. 2004. Evaluation of antibacterial properties of some medicinal plants used in Iran. J Ethnopharmacol. 94(2-3): 301305.

Brophy JJ, Foster PI, Goldsack RJ, Hibbert DB, Punruckvong A. 1997 Variation in Callistemon viminalis (Myrtaceae): New evidence from leaf essential oils. Aust. Syst. Bot. 10(1): 1-13.

Burkill HM, Dalziel JME. 1997. The Useful Plants of West Tropical Africa: Families M-R, $2^{\text {nd }}$ ed., Kew: Royal Botanic Gardens.

Burt S. 2004.Essential oils: their antibacterial properties and potential applications in foods - a review. Int. J. Food Microbiol. 94(3): 223-253.

Ceylan E, Fung DYC. 2004. Antimicrobial activity of spices. J Rapid Methods Autom. Microbiol. 12(1): 1-55.

CLSI. 2009. Performance standards for antibacterial disk susceptibility tests; Approved standards. $10^{\text {th }}$ ed., Wayne, PA: Clinical and Laboratory Standards Institute.

Cock IE. 2008. Antibacterial activity of selected Australian native plant extracts. Internet J. Microbiol. 4(2).

Corbo MR, Di Giulio S, Conte A, Speranza B, Sinigaglia M, Del Nobile MA. 2009. Thymol and modified atmosphere packaging to control microbiological spoilage in packed fresh cod hamburgers. Int J. Food Sci. Technol. 44(8): 1553-1560.

Corbo MR, Speranza B, Filippone A, Granatiero S, Conte A, Sinigaglia M, Del Nobile MA. 2008. Study on the synergic effect of natural compounds on the microbial quality decay of packed fish hamburger. Int. J. Food Microbiol. 127(3) :261-267.

Dainty RH, Shaw BG, Hardinger CD, Michanie S. 1979. The spoilage of vacuum packaged beef by cold tolerant bacteria. In: Russell AD, Fuller R. Cold tolerant bacteria in spoilage and the environment. New York: Academic Press. pp: 83-110.

Devatkal S, Jaiswal P, Jha S, Bharadwaj R, Viswas KN. 2013. Antibacterial activity of aqueous extract of pomegranate peel against Pseudomonas stutzeri isolated from poultry meat. J. Food Sci. Technol. 50(3): 555-560.

Duncan DB. 1955. Multiple range and multiple F test. Biometrics $11: 1-42$.

Ernawita. 2008. Bioassay-guided fractionation and identification of antioxidant and antimicrobial compounds from Callistemon viminalis (Gaertn.) G. Don. MSc Thesis. Penang, Malaysia: Universiti Sains Malaysia.

Gómez-Estaca J, López de Lacey A, López-Caballero ME, GómezGuillén MC, Montero P. 2010. Biodegradable gelatin-chitosan films incorporated with essential oils as antimicrobial agents for fish preservation. Food Microbiol. 27(7): 889-896.

Gram L. 1993. Inhibitory effect against pathogenic and spoilage bacteria of Pseudomonas strains isolated from spoiled and fresh fish. Appl. Environ. Microbiol. 59(7): 2197-2203.

Gram L. Dalgaard P. 2002. Fish spoilage bacteria-problems and solutions. Curr. Opin. Biotechno. 113(3), 262-266.

Gram L, Huss HH. 1996. Microbiological spoilage of fish and fish products. Int. J. Food Microbiol. 33(1): 121-137. 
Gram L, Wedell-Neergaard C, Huss HH. 1990. The bacteriology of fresh and spoiling Lake Victorian Nile perch (Lates niloticus). Int. J. Food Microbiol.10(3-4)303-316.

Gregersen T. 1978. Rapid method for distinction of Gram-negative from Gram-positive bacteria. Appl. Microbiol. Biotechnol. 5(2): 123-127.

Gutierrez J, Barry-Ryan C, Bourke P. 2008. The antimicrobial efficacy of plant essential oil combinations and interactions with food ingredients. Int. J. Food Microbiol. 124(1): 91-97.

Gyawali R, Ibrahim SA. 2014. Natural products as antimicrobial agents. Food Control 46: 412-429.

Hobbs G. 1991. Fish: microbiological spoilage and safety. Food Sci. Technol. Today. 5: 166-173.

Hoque MDM, Bari ML, Inatsu Y, Juneja VK, Kawamoto S. 2007. Antibacterial activity of guava (Psidium guajava L.) and neem (Azadirachta indica A. Juss.) extracts against foodborne pathogens and spoilage bacteria. Foodborne Pathog. Dis. 4(4): 481-488.

Hugh R, Leifson E. 1953. The taxonomic significance of fermentative versus oxidative metabolism of carbohydrates by various Gram negative bacteria. J. Bacteriol. 66(1): 24-26.

Khan MIH, Ahmad J. 1985. A pharmacognosy study of Psidium guajava L. Pharm. Biol. 23(2): 95-103.

Lalitha KV, Surendran PK. 2006. Microbiological changes in farm reared freshwater prawn (Macrobrachium rosenbergii de Man) in ice. Food Control 17(10): 802-807.

Lee JH, Stein BD. 2011. Antimicrobial activity of a combination of Mume fructus, Schizandrae fructus, and Coptidis rhizoma on enterohemorrhagic Escherichia coli O26, O111, and O157 and its effect on Shiga toxin releases. Foodborne Pathog Dis. 8(5): 643-646.

Liston J. 1980. Microbiology in fishery science. In: Connell JJ. Advances in fish science and technology. Aberdeen, Scotland: Fishing News Books. pp: 138-157.

Liu S, Fan W, Zhong S, Ma C, Li P, Zhou K, Peng Z, Zhu M. 2010. Quality evaluation of tray-packed tilapia fillets stored at $0{ }^{\circ} \mathrm{C}$ based on sensory, microbiological, biochemical and physical attributes. Afr. J. Biotechnol. 9(5): 692-701.

Mahmoud BSM, Yamazaki K, Miyashita K, Il-Shik S, Dong-Suk C, Suzuki T. 2004. Bacterial microflora of carp (Cyprinus carpio) and its shelf-life extension by essential oil compounds. Food Microbiol. 21(6): 657-666.

Mejlholm O, Dalgaard P. 2002. Antimicrobial effect of essential oils on the seafood spoilage micro-organism Photobacterium phosphoreum in liquid media and fish products. Lett. Appl. Microbiol. 34(1): 27-31.

Odoli CO. 2009. Optimal storage conditions for fresh farmed tilapia (Oreochromis niloticus) fillets. MSc Thesis. Reykjavik: University of Iceland.

Oonmetta-aree J, Suzuki T, Gasaluck P, Eumkeb G. 2006. Antimicrobial properties and action of galangal (Alpinia galanga Linn.) on Staphylococcus aureus. LWT-Food Sci. Technol. 39(10): 1214-1220.
Pattnaik S, Subramanyam V, Bapaji M, Kole C. 1997. Antibacterial and antifungal activity of aromatic constituents of essential oils. Microbios 89(358): 39-46.

Peter KV. 2001. Handbook of herbs and spices. vol. 1. Cambridge, England: CRC Press.

Rahman N, Furuta T, Kojima S, Takane K, Ali Mohd M. 1999. Antimalarial activity of extracts of Malaysian medicinal plants. J. Ethnopharmacol. 64(3): 249-254.

Sato K, Krist S, Buchbauer G. 2007. Antimicrobial effect of vapours of geraniol, (R)-(-)-linalool, terpineol, $\gamma$-terpinene and 1,8cineole on airbone microbes using an airwasher. Flavour Fragr. J. 22(5): 435-437.

Sharma A, Patel VK, Ramteke P. 2009. Identification of vibriocidal compounds from medicinal plants using chromatographic fingerprinting. World J. Microbiol. Biotechnol. 25(1): 19-25.

Shewan JM, Hobbs G, Hodgkiss W. 1960. A determinative scheme for the identification of certain genera of Gram-negative bacteria, with special reference to the Pseudomonadaceae. J. Appl. Microbiol. 23(3): 379-390.

Singh G, Maurya S, deLampasona MP, Catalan CAN. 2007. A comparison of chemical, antioxidant and antimicrobial studies of cinnamon leaf and bark volatile oils, oleoresins and their constituents. Food Chem. Toxicol. 45(9): 1650-1661.

Srivastava SK, Ahmad A, Syamsunder KV, Aggarwal KK, Khanuja SPS. 2003. Essential oil composition of Callistemon viminalis leaves from India. Flavour Fragr. J. 18(5): 361-363.

Stenström IM, Molin G. 1990. Classification of the spoilage flora of fish, with special reference to Shewanella putrefaciens. J. Appl. Bacteriol. 68(6): 601-618.

Surendran PK, Joseph J, Shenoy AV, Perigreen PA, Mahadeva Iyer K, Gopakumar K. 1989. Studies of spoilage of commercially important tropical fishes under iced storage. Fish. Res. 7(1-2): $1-9$.

Tajkarimi MM, Ibrahim SA, Cliver DO. 2010. Antimicrobial herb and spice compounds in food. Food Control 21(9)1199-1218.

Tryfinopoulou P, Drosinos EH, Nychas GJE. 2001. Performance of Pseudomonas CFC-selective medium in the fish storage ecosystems. J. Microbiol. Methods. 47(2): 243-247.

Tryfinopoulou P, Tsakalidou E, Nychas G-J. 2002. Characterization of Pseudomonas spp. associated with spoilage of gilt-head sea bream stored under various conditions. Appl. Environ. Microbiol. 68(1): 65-72.

Velu S, Abu Bakar F, Mahyudin NA, Saari N, Zaman MZ. 2014. In vitro antimicrobial activity of musk lime, key lime and lemon extracts against food related pathogenic and spoilage bacteria. Int. Food Res. J. 21(1): 379-386.

Weerakkody NS, Caffin N, Turner MS, Dykes GA. 2010. In vitro antimicrobial activity of less-utilized spice and herb extracts against selected food-borne bacteria. Food Control 21(10): $1408-1414$.

Yano Y, Satomi M, Oikawa H. 2006. Antimicrobial effect of spices and herbs on Vibrio parahaemolyticus. Int. J. Food Microbiol. 111(1): 6-11. 